https://helda.helsinki.fi

\title{
Experiencing Oklahoma Archaeology Month 2018
}

\section{Thomas, Suzie}

2019-10-17

Thomas, S 2019 , ' Experiencing Oklahoma Archaeology Month 2018 ' , Public Archaeology . https://doi.org/10.1080/14655187.2019.1671780

http://hdl.handle.net/10138/335380

https://doi.org/10.1080/14655187.2019.1671780

submittedVersion

Downloaded from Helda, University of Helsinki institutional repository.

This is an electronic reprint of the original article.

This reprint may differ from the original in pagination and typographic detail.

Please cite the original version. 


\section{Experiencing Oklahoma Archaeology Month 2018}

Suzie Thomas ${ }^{\mathrm{a}}$

${ }^{a}$ Department of Cultures, University of Helsinki, Finland

PO Box 59 (Unioninkatu 38)

University of Helsinki

FI-00014

suzie.e.thomas@helsinki.fi

\section{Notes on contributor}

Suzie Thomas is Associate Professor of Cultural Heritage Studies at the University of Helsinki, Finland. She is interested in ways in which the public engage with archaeology, and strategies that archaeologists and other heritage professionals find to facilitate this engagement.

\section{Experiencing Oklahoma Archaeology Month 2018}

Oklahoma Archaeology Month (OAM) is an annual event taking place each October (Figure 1), and as the name suggests it encompasses events taking place across the US state of Oklahoma. It is not the only coordinated archaeology events series in the world; the UK has the Festival of Archaeology, for example, and some 37 US states have either an Archaeology Week or Month. These Archaeology Months take place at different times of the year - Alaska has its archaeology month in April, for example, while Georgia's archaeology month is May. However, October is a popular time for state archaeology months, with a total of 16 states in addition to Oklahoma choosing to celebrate archaeology in that month, including California, Michigan and New York. Seasonality must be one factor in this (no archaeology months take place in winter for example), and October also includes the International Archaeology Day (taking place on the third Saturday of October - www.archaeologyday.org). 


\section{OKLahoma Archaeology Month}

Honoring Two Significant Anniversaries in Oklahoma Archaeological Research and Preservation OCTOBER 2OI8

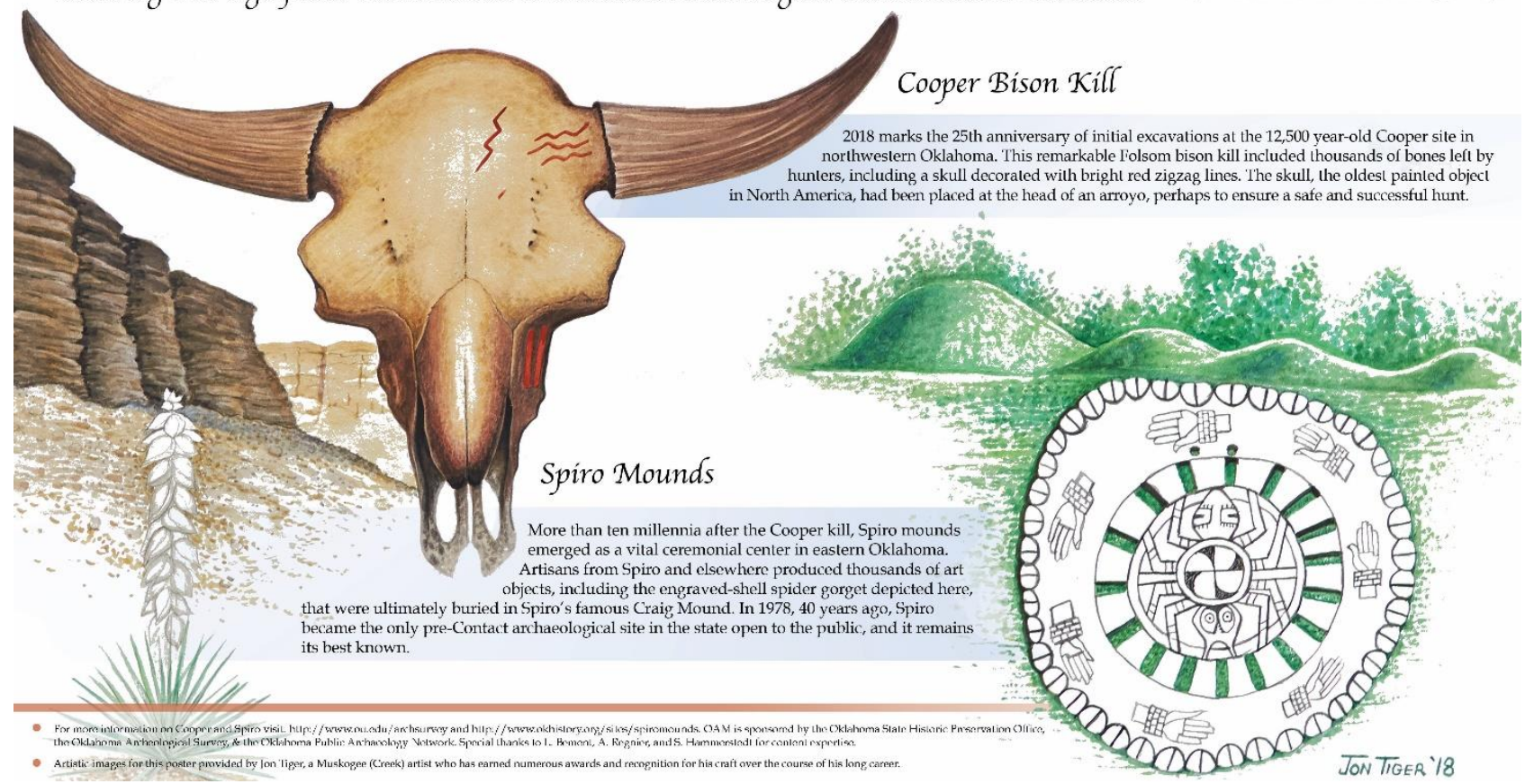

Figure 1 - the promotional poster for Oklahoma Archaeology Month 2019 with artwork by Jon

Tiger, copyright OKPAN.

Among these many celebrations of archaeology, OAM is particularly noteworthy in my opinion. In addition to quickly gaining national recognition ${ }^{\mathrm{i}}$, the significance of OAM is not least due to its remarkable success in becoming a major part of the annual Oklahoma heritage calendar in only a few years of activity. How was this possible? What are the strengths but also the challenges inherent in trying to coordinate these kinds of 'multi-events', which incorporate individual events of many sizes, with different organizers and target audiences, and in different locations? Is this sustainable in the long term; will it grow in popularity and see an increasing number of participating organizers? Or will interest dwindle over time? In this short Profile piece I reflect on what I learned about OAM during an extended research visit to the state, my experiences of some of the events, and lessons that could be valuable for similar event series elsewhere. 
To provide some background, I was lucky enough to spend two months at the University of Oklahoma (OU) in the city of Norman, as an Affiliate Researcher, in September and October of 2018. The Faculty of Arts at the University of Helsinki funded my visit as part of a wider drive at my home university to provide research and teaching staff with international experience, and I especially wanted to come to OU due to the strong reputation for the still relatively new Oklahoma Public Archaeology Network (OKPAN - https://okpublicarchaeology.wordpress.com/). In Finland the concept of public archaeology is still arguably in development, with, until recently, relatively few projects offering opportunities for the wider public to get involved with their archaeological heritage or indeed even to instill the impression that this archaeology is a part of their local sense of place (Soininen 2017, 135). This situation has recently greatly improved, for example with funding available since 2017 from the Finnish Cultural Foundation (Suomen Kulttuurirahasto) to support public archaeology projects, and important initiatives such as the highly successful Adopt-aMonument programme in Pirkanmaa gaining international recognition, becoming a Grand Prix winner of the EU Prize for Cultural Heritage / Europa Nostra Award in 2016. I felt it was important for me to have a chance to return to Helsinki with best practice knowledge and ideas based on what I saw in Oklahoma. I learned a lot just from speaking at length to Faculty staff and graduate students about the organization of OKPAN, and from attending several OAM events.

OAM began in 2014, the initiative of Faculty staff and students in the Department of Anthropology at OU, and specifically the idea of Professor Bonnie Pitblado. She notes that OAM was not unique in that other states already had similar initiatives, but nonetheless for a large state like Oklahoma with a relatively sparse population and diverse archaeology - ranging from internationally important Paleoindian material to rich historical-period archaeology - OAM presents potential for opening this cultural heritage to a wider local audience.

I tried to attend as many events as my schedule would allow, and saw standard, but still effective, models of public archaeology played out. This ranged from open public lectures on a 
range of topics, through to archaeological open days at museums. The public lectures incidentally included delivering one event myself in the form of a talk - also streamed live on Facebook - about public archaeology work in Finnish Lapland as part of the Lapland's Dark Heritage project (see e.g. Banks, Koskinen-Koivisto and Seitsonen 2018 for an overview of the project's public archaeology initiatives). This talk I delivered at OU in Norman, with the added attraction to would-be attendees of a light buffet kindly arranged by my hosts. The talk proved popular: as well as the refreshments offered to audience members, my guess would be that the universal familiarity of the Second World War to most people regardless of their location, combined with the comparative 'exotic' draw of an Arctic region far from this southern Plains state, proved an appealing blend. I had no shortage of questions, ranging from questions on the war history in Finland, to questions about the archaeological discoveries made, through to ethical questions concerning how to present heritage connected with the actions of Nazi Germany to the public without encouraging far-right sentiments.

The content of the talks was important in the two other lecture events that I attended, with local heritage celebrated in significant and sometimes (seemingly) unorthodox ways. Both of these talks took place in the Sam Noble Oklahoma Museum of Natural History, also in Norman. The first was a lecture from avocational archaeologist and artefact collector Jim Cox, showcasing his collections (literally, with many examples present in display cases) and the stories behind them. The big theme of his talk was responsible stewardship. A particularly interesting reflection for me was Cox's emphasis that he had purchased some of his collection not as a financial investment but rather out of a sense of responsibility to keep both material and field notes together, rather than to see the objects (already excavated many decades earlier by historical avocational archaeologists) sold off into the general market by family members inheriting the material, with little appreciation for the information the collections and notes together represented. Cox, who has also contributed to the academic discourse through his own publications (e.g. Cox 2014) is also clear that his collections will go into a museum once he is passed away. This sense of stewardship (rather than ownership) 
was clear throughout his talk. The lecture was also an Oklahoma Anthropological Society event for the Cleveland County Chapter, with joint-badging due to it taking place in October. The audience he attracted was a range of graduate students, faculty and OAS members, all with plenty of questions and comments.

A second lecture I attended at Sam Noble Museum was about the iconic Paleoindian Cooper Bison Kill site in Harper County, Oklahoma. Presenter Dr Leland Bement directed the excavations (see Bement 1999), and his talk in honour of the $25^{\text {th }}$ anniversary of the site's discovery provided scientific content as well as an important human element in recounting the conditions and anecdotes from the fieldwork. This included Bement's very personal account of his discovery of the famous painted bison skull, and the emotions and stress surrounding trying to excavate it safely in terrible weather conditions. Other events included an 'Archaeo-barbecue' in Tulsa, which I could not attend due to schedule clashes but which sounded like a fun way to combine archaeological discussion with straightforward socializing. Luck was also against me in some cases - a reminder that the best intentions can be scuppered by inclement weather; especially in a part of the world as famous for its extreme conditions as Oklahoma. While I only experienced one tornado alert in my two months in Oklahoma (thankfully apparently not causing any injuries, nor affecting any of the OAM events), heavy rain meant that I did not get to see Oklahoma Anthropological Society's public excavation at Muldrow. It ran for only one day of its planned long weekend, and by the time of the second day, when I had planned to visit, it was delayed and then canceled due to the state of the roads. Here social media proved invaluable in informing would-be visitors and participants in order to save them a wasted, even hazardous journey.

Similarly a graveyard survey at Hopper Cemetery, in the town of Wayne the following weekend (another event I had earmarked to attend), faced cancellation due to local flooding. Bad weather is of course a risk for any outdoor events, and it is not always possible to plan contingency 





Pitblado, B. 2014. An argument for ethical, proactive, archaeologist-artifact collector collaboration. American Antiquity 79(3): 385-400.

Soininen, T.-L. 2017 Adopt-a-Monument: Preserving archaeological heritage for the people, with the people. Journal of Community Archaeology \& Heritage 4(2): 131-7.

Thomas, S. 2018. Event review: Archaeology day. Journal of Community Archaeology \& Heritage 5(4): 268-71. 